\title{
Heresy and Orthodoxy Now: The Zigzagging Paths of the Lawful
}

\section{ABSTRACT}

In this article I consider a certain characteristic of our times as a "secular age," namely, a series of complications in our understanding of transgression. Transgression implies the presence of some rules and laws which can be violated. As long as the rules and laws are perceived as right, as a way of protecting the values which would otherwise perish, transgression appears to be a wrong thing to do, a misdeed, a criminal act. Needless to say, the very conceptual structure makes sense only provided that the distinctions between right and wrong, good and evil, lawful and lawless are not arbitrary, which, in turn, depends on the presence of the concept of truth.

In the secular age, though, the concept of truth becomes not only difficult to handle, since it is incompatible with the modern frame of mind, but also assumes some derogatory connotations, up to the point when to insist on the distinction between (truly) right and (truly) wrong is in itself a wrong thing to do. That is the state of contemporary societies which G. K. Chesterton examines in his work Heretics. The effect of Chesterton's reflections is a new map of right/wrong, good/evil, lawless/ lawful permutations. After Chesterton, I comment on the character of a new beretic, one for whom transgression, understood as the attack on buried-for-long orthodoxy, is too easy a thing to do. To illustrate the mentioned changes of perspective, I refer to an exemplary criminal figure of the West, that is, the biblical serpent, and its criticism.

Keywords: G. K. Chesterton, heresy, orthodoxy, the biblical serpent, secularization. 
1.

Apparently, a prototypical criminal figure of the literary West is the biblical serpent. The serpent persuades the first woman into the originary act of transgression; the serpent stands behind the scene of disobedience and effectively encourages others to cross the boundaries of the lawful; the serpent is afterwards judged and punished by God, cursed by Him and condemned to eating the ashes and crawling on the earth to the end of its days, the verdict in itself telling a story of downfall, degradation and exclusion. But the serpent remains an ambiguous figure and has provoked in the cultural history a whole spectrum of responses, many of which would suggest something more like a rogue identity than simply that of a criminal. If the biblical transgressor and seducer does not turn overtly into a lovable creature, admired for the adroitness of its naughty conduct, it may still appear to be less detestable than the rules imposed on the first humans by the demanding voice of their Creator. Before I reach that particular point about the biblical serpent, I will present an exemplary selection of contemporary analyses of its character and mission.

In the essay "Sexuality, Sin and Sorrow" Mieke Bal admits that the biblical serpent was "an ambivalent creature, ontologically, morally, as well as narratologically" and explains that it was ambivalent ontologically as the animal which talked (31). In regard to its narrative position, Bal notices, in turn, that the appearance of the serpent brings the possibility of action whose clarity is yet effectively blurred: who is the actant? the protagonist? the antagonist? are the ongoing questions (35-36). As to the moral ambivalence, symbolized by the proverbial slyness of the animal, in Bal's view the serpent's conduct "implies cleverness, but not necessarily deceit" (32). It is worth noticing how the last point, the claim about the relative arbitrariness of the cunning animal's speech, is made. While commenting on the serpent's key interrogation ("Yea, hath God said, Ye shall not eat of every tree of the garden?", Gen 3,1b) in the way that she does- “ $[\mathrm{p}]$ resenting God's interdiction as so absolute, so tyrannical, the serpent provokes revolt" (32)—Bal seems to take the transgressor's side. Even though she notices that what God said was about one and not every tree, it is stated in a rather tentative manner: "Yahweh said seemingly the opposite," and followed by a complex philological and philosophical elaboration on the one-or-two-tree(s) issue (32-33). In consequence, one thing remains clear: God did include some "no" or "not" in His first description of man's position in the world, and that alone may suffice to present man's negative reaction to His commandment as more than natural. I have to admit that my presentation of Bal's argument may have been slightly exaggerated, but the fact is that the difference between 
"cleverness" and "deceit," as presented in her analysis, comes down to nothing more than a subtle distinction between speaking in an allusive rather than straightforward manner. Is it really a difference in kind? If not, the serpent can easily be saved from infamy.

André LaCocque, in his philosophical study co-written with Paul Ricoeur, draws our attention to the same descriptive formula of the serpent-its cunning nature-and maintains that in purely linguistic terms the description is not necessarily pejorative (29). He recalls the use of the same word in Proverbs (14,15.18; 22,3; 27,12), where "cunning" assumes the positive meaning of "prudent" (29). What LaCocque adds to the reading of Hebrew arum (cunning; prudent) is its possible correspondence with arom (naked), the connection which opens space for the sexual reading of the serpent and woman's encounter. It is also due to the similarity between the two terms, arum and arom, that the animal nature of man is brought into play and the serpent's attack assumes the meaning of man's inner struggle with sexual instincts (29-30). LaCocque does not consider, then, the criminal potential of the serpent but discusses instead its symbolic meaning, in the larger, mythical context and, specifically, in Genesis, chapter 3 .

The interplay between arum and arom is also recognized by Zdzisław Pawłowski, who gives a more developed commentary on the way in which the cunning animal speaks. To Pawłowski, the serpent is primarily a voice. The serpent is the voice which comes from the outside of the God-man relationship, from the outside of any relationship, in fact, and thus, deprived of subjectivity, it assumes the tone of pure objectivity. The major rhetorical strategy of the serpent is to include God within the confines of its speech. Then, the subject matter is still of some importance, but God's status and His relationship with man are, significantly, altered. Man finds himself in a position enabling him to discuss God's ways in front of another earth creature brought to life with the Creator's breath (Pawłowski 389-90).

To bring one more approach into this presentation, let me mention Phyllis Trible, who in her work God and the Rhetoric of Sexuality disembodies the serpent even more, saying that it was "a villain in portrayal," but "a device in plot" (111). In her view, the serpent is, certainly, a villain, but the story as such is not about the villain and its victims, even less about evil. Evil is an abstract term, and rather powerless unless some concrete meanings become a part of its semantic realm. Why should man obey God? Why should he observe the rules beyond his comprehension? Trible claims that the story develops mainly to inform about man's existential position. More than about the malicious deeds of a sly creature it speaks about human obedience to God understood as life and human disobedience to God understood as death (111). The character of the serpent serves as 
a tool in this respect, as a means of exposing the most fundamental tension inscribed in the human condition. In regard to this larger objective, the ambiguity of the serpent's literal description may remain unsolved.

2.

Needless to say, the scene under scrutiny, the so-called scene of temptation, is the first place in the biblical text where we read about good and evil and thus, possibly, a reference point for the discussion of moral and ethical issues. Yet the critical approaches just outlined are a mixture of theological, philosophical, philological and linguistic tropes. None of them aim at the formulation of a clear ethical message, nor promote a specific reading of the serpent's conduct; their function is not to teach morals but to perform a professional reading of the biblical lines. Regardless of their personal views and beliefs, ${ }^{1}$ the authors shun a style which could be labelled as personal or even stigmatized as confessional. Does it matter? How does it matter from the perspective of my argument?

What I want to note at its preliminary stage is, first, that nowadays, with the exception of the texts whose authors represent so-called cultural minorities, critical pieces should not display personal beliefs. This seems to be an all-too-obvious profile of an academic text now. Secondly, and not without some logical connection to my first remark, when opinions and statements are attributed purely political significance, the participants of public debates may feel discouraged from holding and formulating truly personal ideas. More and more often worldviews count as commodities in public exchanges rather than as precious life directions which one is ready to protect and fight for. And even though I thereby name a tendency and not the status quo, one may say "a tendency and not the status quo-yet," which is disturbing enough. But let me also say clearly that, personally, I do find all these serpent-centred debates fascinating and by no means do I opt for replacing them with moral tales. So-what is the point?

My point is that in the world where the very presence of clear-cut distinctions (like good and evil, lawful and lawless, true and false) is not taken for granted any longer, the concept of "a bad guy" maintains its negative connotations in the legal context alone, if at all. Everywhere else it may become subject to endless negotiations. The (good old?) times when "God" connoted simply "goodness" and "Satan" "evil" are long gone. What theology names the Fall and perceives as the first lost battle of

1 Let me note on this occasion that Pawłowski, for instance, is a scholar, but also a Catholic priest. 
humanity, the tragic moment when love is betrayed and "the hope of God is gone" (Chesterton, Orthodoxy 34), in contemporary critical discourse is likely to be approached in a much more light-hearted manner: for instance, as the encounter between the (impersonal) Law and the (personal) alltoo-human longing for the fulfilment that the Law persistently forbids, or, more specifically, as the combat between the law and ... the apple. Here, to complete my list of biblical readings, I refer to a widely known representative of the mentioned cultural minorities, a French feminist, Hélène Cixous, and her presentation of the scene in question:

What is at stake here is the mystery assailed by the law, the law which is absolute, verbal, invisible, negative ... its force is its invisibility, its non-existence, its force of denial, its "not." And facing the law, there is the apple which is, is, is. It is the struggle between presence and absence, between an undesirable, unverifiable, indecisive absence, and a presence, a presence which is not only a presence: the apple is visible and it can be held to the mouth, it is full, it has an inside. And what Eve will discover in her relationship to simple reality, is the inside of the apple, and that the inside is good. (133)

One will easily notice in Cixous's argument a playful composition of binary opposites as if dancing in front of our eyes, a misty (misty-serious?) replacement of the former world founded on mystery, yet clear and harmonious in its outward design. No division into good and evil, reality and non-reality, truth and lie, life and death, presence and absence, in the former senses, but instead the evil Law, associated with non-existence and absence, is contrasted with a good (presence of the) apple, the evil law with good fulfilment, the evil presence of law (God is not even mentioned, the law is the only trace of Him) with the good presence of the apple (and the mouth). Man is the mouth in need of the apple and a bad guy (law, God) stands in the way. A nice story, artistic and persuasive, but where will it bring us? The abandoning of moral distinctions for the sake of satisfying one's immediate appetites is a thought to be seriously considered. When subject to artistic processing, it loses all its sharpness and depth.

3.

One of the most exhaustive and acclaimed studies of our times as affected by growing secularization is Charles Taylor's A Secular Age. There he gives the preliminary meaning of secularization, pointing at three directions which the process may assume. First, it is about the "public spaces emptied of God" (2), that is, the receding of religion from the public square, the division between 
the State and the Church; secondly, Taylor takes into account the liveliness and vigour of the religious practices themselves and recalls another wellknown factor of today's cultural landscape: the falling away of belief in God, "people turning away from God, and no longer going to Church" (2); finally, as the third direction assumed and the third sense of secularization, Taylor outlines the proper subject of his study, that is, the most thorough change in the very conditions of belief: the transition from the former societies, where "it was virtually impossible not to believe in God," to one in which God is one of multiple, contested options (3). When faith is "one human possibility among others," even in the eyes of staunch believers their belief is nothing more than "an embattled option" (3). Taylor insists that a society should be considered secular, or not, in terms of its pre-ontology: "the whole context of understanding in which our moral, spiritual or religious experience and search take place" (3), that is, on the basis of the third criterion. In his view, the West (the North Atlantic world) has been secular in the pre-ontological sense at least since the mid-nineteenth century.

What Taylor also suggests is that in a world in which God is one of many possible choices, "an option among options," "an alternative among alternatives," nothing can be reckoned absolute, ultimate, unconditional; things, ideas and deeds are prone not to have definite meaning, so that the concept of truth also gradually becomes obsolete and out of place. Then, life is not regulated any longer, the rules become arbitrary, choices-dictated by changing historical and cultural conditions. That, in turn, radically transforms the very concept of rebellion and affects our understanding of what is lawful and what is not. We used to associate rebellion with an attack on the status quo, the questioning of the existent law, breaking the rules. But what if the rule is that there are no rules? And the only law is that no laws should govern our lives?

It is time to proceed to the actual inspiration for this paper, a text published in 1905, written by a man born in 1874, where he speaks, in his inimitable style, both playful and sharp, about "an enormous and silent evil of modern society." The text and the man that I have in mind is Heretics by G. K. Chesterton, and the complete sentence goes: "Nothing more strangely indicates an enormous and silent evil of modern society than the extraordinary use which is made nowadays of the word 'orthodox"' (3).

\section{4.}

Among other concepts, Chesterton reflects on rebellion and rebels. But the cultural and social scene which he examines is so disorganized that the use of those terms should by no means be automatic. To be 
able to call somebody a rebel or not, we have, first, to clearly see what has happened, what changes the modern man has undergone in relation to the rules themselves. What is, then, "the extraordinary use which is made nowadays of the word 'orthodox," what is significant about the change with the description of which Chesterton opens his argument? The meaning attributed to "orthodoxy," valid for ages, was truth, so that being orthodox implied being right, being on the side of truth, knowing what is true. Consequently, the opposite term of "orthodoxy" - that is, "heresy"-meant simply "falsehood"; heretics were reckoned to hold false beliefs about reality, about the matters which really mattered. Then, during Chesterton's times (but I assume that also since then) to be orthodox does not mean being right any longer, but its exact opposite: being wrong; heresy, in turn, is not what others are blamed for, but names a position which many a man, willingly and eagerly, claims for himself. People call themselves heretics with pride and self-satisfaction, while only a few would accept the stigma of orthodoxy. Certainly, when heresy and orthodoxy changed places in the manner thus outlined, the terms must have altered in the very process. Or, more precisely, the reality in which heresy and orthodoxy operated has altered so significantly that its descriptive terms could not remain the same.

It hardly needs recalling that the major factor behind the mentioned reversal of meanings was the spreading of scientific positivism and the consequent waning of the concept of truth in the metaphysical sense of the word, the end of the belief that the distinction between true and false is at work also outside the logical-mathematical and scientific context. When truth and falsity are subject to scientific examination, views on reality in its deeper, metaphysical sense appear to be meaningless and of no value. In this way the modern man, before he lost his religious beliefs, was deprived of the motivation to possess any kind of philosophy, a coherent and consistent world-view of things in their entirety. "Everything matters-except everything" (Chesterton, Heretics 5). This is how it becomes possible that somebody "says with a conscious laugh, 'I suppose I am very heretical,' and looks round for applause” (4). This is how " $[t]$ he word 'heresy' not only means no longer being wrong; it practically means being clear-headed and courageous" and "[ $t]$ he word 'orthodoxy' not only no longer means being right; it practically means being wrong” (4). Having a philosophy, pronouncing a definite worldview, has become so obsolete that in the face of the new cultural standards it is almost shameful and unruly to admit in public that you still have one. This is the new mental environment which Chesterton names for us and in which one may seriously wonder where the former act of rebellion should be allocated. 
But Chesterton names yet another paradox and permutation. The concept of truth, he reminds us, was banned from public space for the sake of another ideal: the freedom of speech. The concept of truth was abolished so that everybody could freely voice their views: "When the old Liberals removed the gags from all the heresies, their idea was that religious and philosophical discoveries be made. Their view was that cosmic truth was so important that everyone ought to bear independent testimony" (Heretics 6). Still, the perverted effect of the postulate of the freedom of speech being realized is that people, free to say anything, do not say anything important, because nothing is important any longer. At times when freedom of speech is the only absolute, people have opinions, not beliefs. So, as Chesterton ironically remarks, they will engage themselves in passionate debates on the weather, Botticelli and tramcars (5). In a way, silence falls, because the phatic, meaningless babble does not count as words.

I have to admit that my presentation of the problem was not very nuanced, which I realize. Life is always more complicated than its brief descriptions. But I hope that at least one thing was shown: indeed, nowadays, we have to be careful when speaking about transgression, crossing the borders, being lawful or lawless. Contemporary rebels, rebels at hearts, not by name, can be very orthodox. They do not attack but defend. And Chesterton himself, along with others like him, was very much in that fashion.

\section{5.}

One of Chesterton's biographers refers to him as a man fighting against "the tyranny of his age." An element in that fight was, no doubt, Chesterton's conversion to Catholicism, the culmination of a long process, not left unnoticed by the London community, with the ceremony of Chesterton's baptism commented on in newspapers and noted in public debates (Pearce 88-101). But there were many others like him. In his lengthy study Literary Converts. Spiritual Inspiration in an Age of Unbelief, Joseph Pearce gives a detailed historical and sociological account of the literary people of the nineteenth and early twentieth century who made the uneasy decision of leaving the Anglican Church and joining the Catholic community, or, more generally, "came out" as Christians. Even after J. H. Newman's famous conversion, the decision demanded personal courage and determination. Catholicism still provoked grim associations with the utterly mistaken religious position, while religion itself was, in Aidan Nichols's words, something "low-key—not to be mentioned aloud in good company" (160). Holding religious beliefs could, then, be accepted, but only as a matter of 
little significance, and not as the pronouncement central to the life of an emancipated individual. The atmosphere of that kind can be clearly sensed in Virginia Woolf's famous statement about T. S. Eliot's conversion:

I have had a most shameful interview with poor dear Tom Eliot, who may be called dead to us all from this day forward. He has become an Anglo-Catholic, believes in God and immortality, and goes to church. I was really shocked. A corpse would seem to me more credible than he is, I mean there's something obscene in a living person sitting by the fire and believing in God. (Woolf 457)

Woolf's words hardly call for a commentary. It is quite explicit that "poor dear Tom," one of the living dead after his reckless and inconsiderate step into the mire of religious superstitions, provokes in the enlightened minds not simply pity, but a mixture of disgust and apprehension. $\mathrm{He}$ crossed the boundaries of good taste and broke the rules of socially appropriate behaviour. Could it be said that "poor dear Tom" and his like embody the figure of the contemporary transgressor, and thus become a testimony to the endless permutations, the zigzagging paths, of our concepts of good and evil, lawfulness and lawlessness, the accepted and the unacceptable?

\section{Works Cited}

Bal, Mieke. "Sexuality, Sin and Sorrow. The Emergence of the Female Character (A Reading of Genesis 1-3).” Poetics Today 6.1-2 (1985): 21-41. Print.

Chesterton, G. K. Heretics. London: The Bodley Head, 1960. Print.

---. Orthodoxy. U.S.A.: Popular Classics, 2012. Print.

Cixous, Hélène. "Extreme Fidelity." Hélène Cixous Reader. Ed. Susan Sellers. London: Routledge, 1994. 129-38. Print.

LaCocque André, and Paul Ricoeur. Myśleć biblijnie. Trans. Ewa Mukoid and Maria Tarnowska. Kraków: Znak, 2003. Print.

Nichols, Aidan. The Panther and the Hind. A Theological History of Anglicanism. Edinburgh: T\&T Clark, 1993. Print.

Pawłowski, Zdzisław. Opowiadanie, Bóg i początek. Warszawa: Oficyna Wydawnicza „Vocatio,” 2003. Print.

Pearce, Joseph. Literary Converts. Spiritual Inspiration in an Age of Unbelief. San Francisco: Ignatius, 2000. Print.

Taylor, Charles. A Secular Age. Cambridge, MA: The Belknap P of Harvard UP, 2007. Print. 
The King James Bible. Kingjamesbibleonline.org. Web. 23 Jul. 2019.

Trible, Phyllis. God and Rhetoric of Sexuality. Philadelphia: Fortress, 1983. Print.

Woolf, Virginia. “To Vanessa Bell.” 11 Feb. 1928. Letter 1858 of The Letters of Virginia Woolf. Volume 3. Ed. Nigel Nicolson and Joanne Trautmann. San Diego, CA: Harcourt Brace Jovanovich, 1977. 457-58. Print.

Marta Zając (D. Litt.) is Associate Professor at the Institute of British Cultures and Literatures, the University of Silesia, Poland. Her publications include the monographs The Feminine of Difference (Peter Lang, 2002) and Przestrzeń kobiety w chrześcijańskiej koncepcji Boga [The Space of the Feminine in the Christian Concept of God] (Katowice, 2013), as well as numerous articles in the field of literary theory, gender studies and theology of culture.

marta.zajac@us.edu.pl 